\title{
稲田花崗岩の引張応力下における異方性に関する考察
}

甲村雄一*

\section{A Study on Anisotropy under Tensile Stress of Inada Granite}

by

\author{
Yuichi KoHMURA*
}

There is little research on the mechanical characteristics of rock under tensile stress compared with the research on compressive stress. In this study, firstly, direction, length and number of micro cracks were investigated using Inada granite. Secondly, the uniaxial tension test is carried out with the specimen produced in a different direction, an anisotropy of uniaxtial tensile strength, Young's modulus and Poisson's ratio are investigated. In addition, to focus on the effective sectional area of the specimen, considered results on anisotropy of Young's modulus and uniaxial tensile strength were described.

Key words: Granite, Anisotropy, Tensile stress, Micro crack, Young's modulus, Poisson's ratio

\section{1 緒言}

花崗岩はマイクロクラックを含んでおり，その配向性 に起因するいわゆる石の目が存在する。これらは割れや すい順に Rift plane, Grain plane および Hardway plane と 呼ばれている. 1) 花崗岩を対象とした研究は数多く行わ れており、長田ら ${ }^{2)}$ および加藤ら ${ }^{3)}$ はマイクロクラッ クの分布そのものに着目した研究を行っている.また、 圧縮応力下における力学特性に関しては, 一軸圧縮強度 や変形特性の異方性に着目した研究 ${ }^{4)}$ ６)，ダイレイタ ンシーの異方性に着目した研究 ${ }^{7)}$, 繰返し応力下におけ る変形特性の異方性に着目した研究 ${ }^{8)}$, 完全応力ーひず み曲線の post-failure 領域での異方性に着目した研究 ${ }^{9)}$ などが行われ、多くの知見が蓄積されている.

一方，引張応力下における力学特性に関しては，圧裂 引張強度の異方性に着目した研究 4)，10)，一軸引張試験 による強度や変形特性に着目した研究 11) 13) , 一軸引張 試験時の割れ目の異方性に着目した研究 ${ }^{14)}$, 一軸引張試 験による完全応力ーひずみ曲線に関する研究 15) 17)など が行われ，応力ーひずみ曲線が非線形的特性を呈するこ と, 引張応力下におけるヤング率が圧縮応力下における ヤング率に比べて小さいことなどが知られている。しか し, 引張応力下における研究は, 圧縮応力下における研 究に比べると数が少なく, いまだ研究の余地が残されて いる。

本研究では，まず，弾性波速度およびマイクロクラッ クの観察により, マイクロクラックの配向性を確認する. 次に， 2 種類の方向に供試体を作製して一軸引張試験を 実施し, 一軸引張強度, ヤング率およびポアソン比の異 方性を確認寸る。ささに，マイクロクラックを考慮した 供試体の有効断面積に着目し，ヤング率および一軸引張 強度の異方性が有効断面積を考慮することで説明可能 であることを考察した結果について述べる。

\section{$2 \cdot 1$ 試験に用いた供試体}

2 マイクロクラックの配向性

試験には茨城県笠間市産の通称稲田花崗岩を用いた。 サンプリングは $250 \mathrm{~mm}$ 角の立方体ブロックで行い，こ の際，ブロックの各面が現地で経験的に知られている Rift plane, Grain plane および Hardway plane に一致する ようにした. 後述する一軸引張試験用の供試体は直径 35 $\mathrm{mm}$, 高さ $100 \mathrm{~mm}$ とし, Rift plane に垂直な方向（以下 $\mathrm{R}$ 方向と呼ぶ）および Hardway plane に垂直な方向（以 下 $\mathrm{H}$ 方向と呼ぶ）に作製した. 端面の平行度および平坦 度は $1 / 100 \mathrm{~mm}$ 以内とした。供試体作製後, 3 か月間室 内で乾燥した後に試験に用いた。

マイクロクラック観察用の顕微鏡薄片は, Grain plane で作製し、観察結果の再現性を確認するため 2 枚の薄片 を使用した。

\section{$2 \cdot 2$ 弾性波速度試験}

一軸引張試験に先立ち，各供試体で超音波パルス法に より弾性波速度（P波）を計測した。計測結果を Table1 に示す. R方向の平均值は $4.57 \mathrm{~km} / \mathrm{s}, \mathrm{H}$ 方向の平均值は $4.97 \mathrm{~km} / \mathrm{s}$ であり R方向の方が弾性波速度が小さかった. このことからマイクロクラックは Hardway plane に比べ て Rift plane に多く存在することが推察される.

$2 \cdot 3$ マイクロクラックの観察

作製した顕微鏡薄片の拡大写真を Fig.1 に示寸. 本研 究でいうマイクロクラックとは, Fig.1 に示すように鉱物 粒子内に存在するき裂である。マイクロクラックの配向 性およびその数を確認するため, Grain plane で作製した 顕微鏡薄片の観察を行った．Fig.2 に示すように Grain plane で作製した薄片中心から Rift plane に平行な方向

（以下 Rift方向と呼ぶ）および Hardway planeに平行な 方向（以下 Hardway 方向と呼ぶ）に一致するように長さ $40 \mathrm{~mm}$ 北 2 本の直線を引き，この直線に交わるマイクロ

$\dagger$ 原稿受理 平成25年10月23日 Received Oct. 23, 2013 @2014 The Society of Materials Science, Japan

* 正会員 (株)竹中工務店技術研究所 ₹270-1395 印西市大塚，Takenaka R\&D Inst, Ohtsuka, Inzai 270-1395 
Table1 P-wave velocity of specimens.

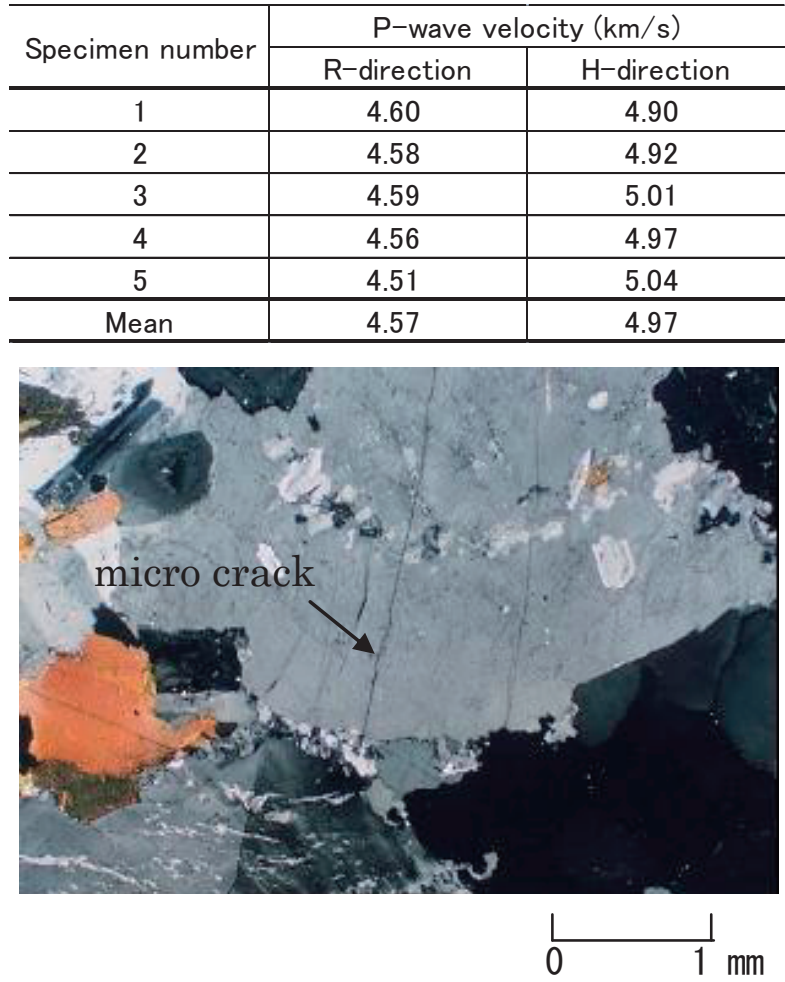

Fig.1 Photograph of Inada granite.

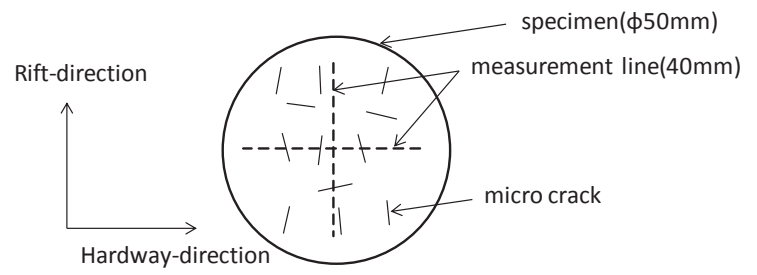

Fig.2 Schematic diagram of micro crack observation.

Table2 Result of micro crack observation.

\begin{tabular}{c|l|c|c|c}
\hline \multicolumn{2}{c|}{} & \multicolumn{3}{|c}{ Specimen number } \\
\cline { 3 - 5 } \multicolumn{2}{c|}{} & 1 & 2 & Mean \\
\hline \multirow{2}{*}{$\begin{array}{c}\text { Number of } \\
\text { micro cracks }\end{array}$} & Rift-direction $\pm 45^{\circ}$ & 25 & 37 & 31 \\
\cline { 2 - 5 } & Hardway-direction $\pm 45^{\circ}$ & 8 & 12 & 10 \\
\hline $\begin{array}{c}\text { Mean micro } \\
\text { crack length } \\
(\mathrm{mm})\end{array}$ & Rift-direction $\pm 45^{\circ}$ & 0.60 & 0.70 & 0.66 \\
\cline { 2 - 5 } & Hardway-direction $\pm 45^{\circ}$ & 0.89 & 0.41 & 0.60 \\
\hline \multicolumn{2}{c|}{$\begin{array}{c}\text { Total micro crack length } \\
(\mathrm{mm})\end{array}$} & 22.00 & 30.65 & 26.33 \\
\hline \multicolumn{2}{c}{ minyyyy}
\end{tabular}

クラックの方向，長さおよび数を調べた．結果を Table2 に示す． 2 枚の薄片で観察を行ったが，いずれの薄片に おいても Rift 方向 $\pm 45^{\circ}$ の方向のマイクロクラックの数 は, Hardway 方向 $445^{\circ}$ の方向の数の約 3 倍という結果 が得られた。マイクロクラックの平均長さは，2つの薄 片でRift方向 $\pm 45^{\circ}$ の方向と Hardway方向 $445^{\circ}$ の方向 で差が見られたが， 2 枚の薄片の平均值をとると Rift 方 向 $45^{\circ}$ で $0.66 \mathrm{~mm}$, Hardway 方向 $\pm 45^{\circ}$ で $0.60 \mathrm{~mm}$ と 10\%程度の差であり，大きな差は見られなかった。

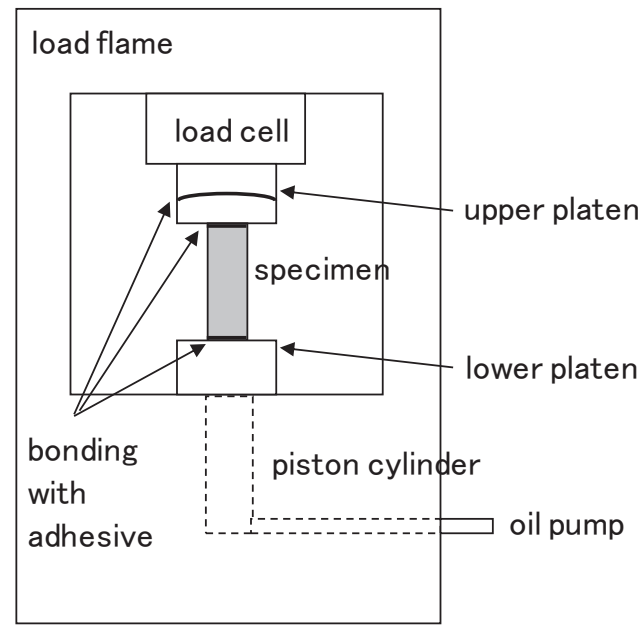

(a) Load flame

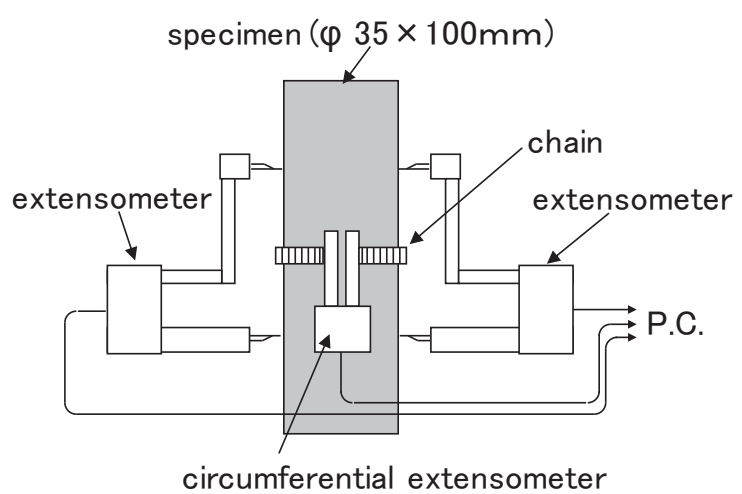

(b) Extensometer

Fig.3 Schematic diagram of the test.

\section{$3 \cdot 1$ 試験方法}

\section{3 一軸引張試験}

試験装置の概念図を Fig.3(a),(b)に示す。試験はR方向 (Rift plane に垂直な方向) およびH方向（Hardway plane に垂直な方向）の直径 $35 \mathrm{~mm}$, 高さ $100 \mathrm{~m} \mathrm{~m}$ の供試体を 用い, $0.5 \mathrm{k} \mathrm{N}$ の圧縮荷重をかけた状態で供試体の上下端 面および供試体上部に設けた球座をエポキシ樹脂製の 接着材で接着し，4 時間放置して接着剤が硬化後試験を 行った. 試験は応力速度一定 $(0.1 \mathrm{MPa} / \mathrm{s})$ の条件で行っ た.

供試体の応力は，供試体上部に設けたロードセルで測 定した荷重を供試体の初期断面積で除すことにより求 めた.ひずみの測定は測定間隔 $50 \mathrm{~mm} の 2$ 点を点接触さ せる軸ひずみ計を対面上に 2 個設置し, その平均值を軸 ひずみとした。周ひずみは供試体にチェーンを巻きつけ, チェーン端部の変位を測定し，これを周ひずみに換算し て求めた。軸ひずみおよび周ひずみともに測定時の分解 能は約 $3 \times 10^{-6}$ であった。 


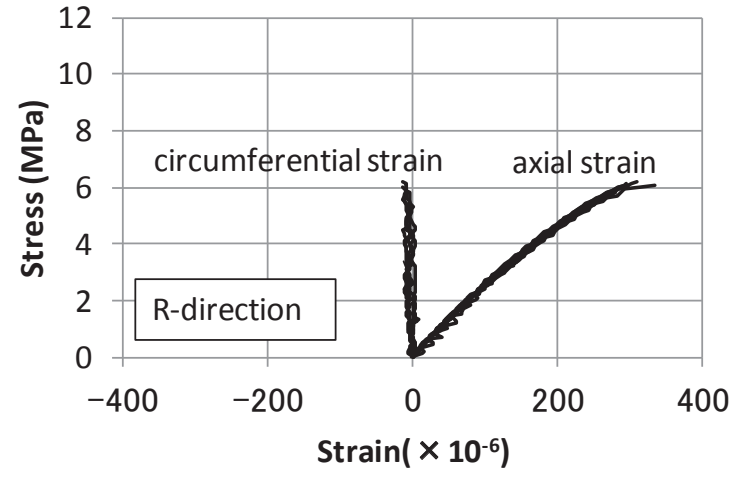

(a) R-direction

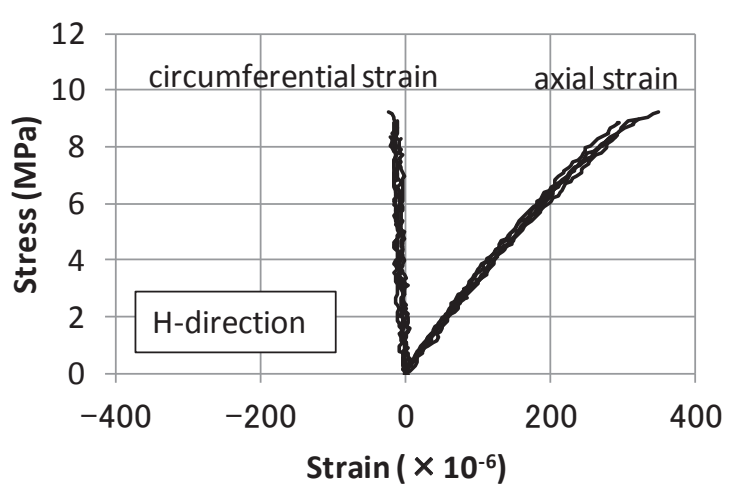

(b) H-direction

Fig.4 Stress-strain curves of uniaxial tension tests.

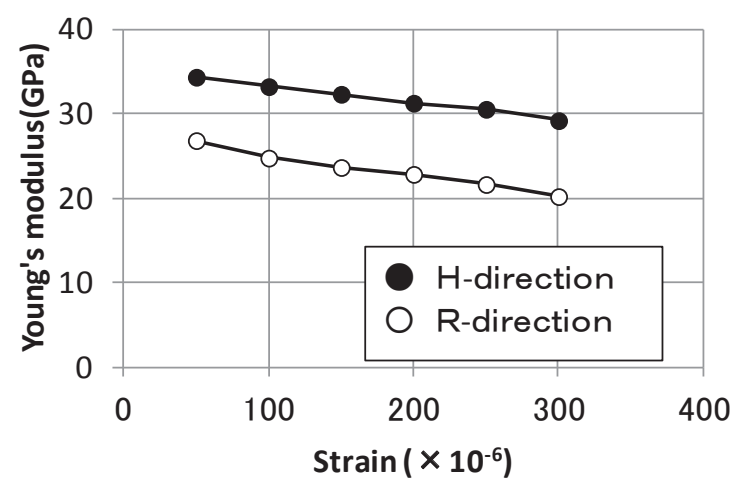

Fig.5 Relation between secant Young's modulus and strain.

\section{$3 \cdot 2$ 試験結果}

R方向およびH方向で各 5 本の供試体で得られた忍 カーひずみ曲線を Fig.4(a),(b)に示す. 本研究では応力お よびひずみのいずれも引張側を正として示す。 $\mathrm{R}$ 方向と $\mathrm{H}$ 方向を比較すると, 一軸引張強度は R 方向で明らかに 小さく，異方性を示すことが確認された。これはH方向 に比べて $\mathrm{R}$ 方向には載荷軸に垂直なマイクロクラック が多く含まれているためと考えられる。なお，破断面は 軸ひずみの測定区間である $50 \mathrm{~mm}$ の内部と外部に生じ たものが混在する結果となった。両者で応力ーひずみ曲 線に大きな差は認められなかった。試験を応力速度一定 の条件で実施したため, 応力が増加して引張破壊が始ま ると，ごく短時間のうちに破壊が終了する．今回はデー タのサンプリングを 1 秒間隔で行った。このため, 引張 破壊の開始から終了までのごく短時間の軸ひずみおよ び周ひずみの変化は計測できていない。今回計測された 軸ひずみおよび周ひずみは，破壊が開始する直近のひず みと考えられる。

ひずみレベルごとに割線ヤング率を求めた結果を Fig.5 に示す．R方向とH方向とでは明らかに割線ヤング率の 值に差が見られ，異方性が確認できる。なお， $\mathrm{R}$ 方向お よびH方向ともにひずみレベルの増加に伴い割線ヤン グ率は低下している。このことから，ひずみレベルが小 さい領域からマイクロクラックの進展が生じているこ とが推察される。なお，ヤング率は弾性領域内において 定義する弾性係数である，今回の場合，ひずみレベルが
Table3 Poisson's ratio at uniaxial failure.

\begin{tabular}{c|c|c}
\hline Specimen number & R-direction & H-direction \\
\hline 1 & 0.027 & 0.036 \\
\hline 2 & 0.027 & 0.082 \\
\hline 3 & 0.020 & 0.027 \\
\hline 4 & 0.045 & 0.069 \\
\hline 5 & 0.043 & 0.075 \\
\hline Mean & 0.032 & 0.058 \\
\hline
\end{tabular}

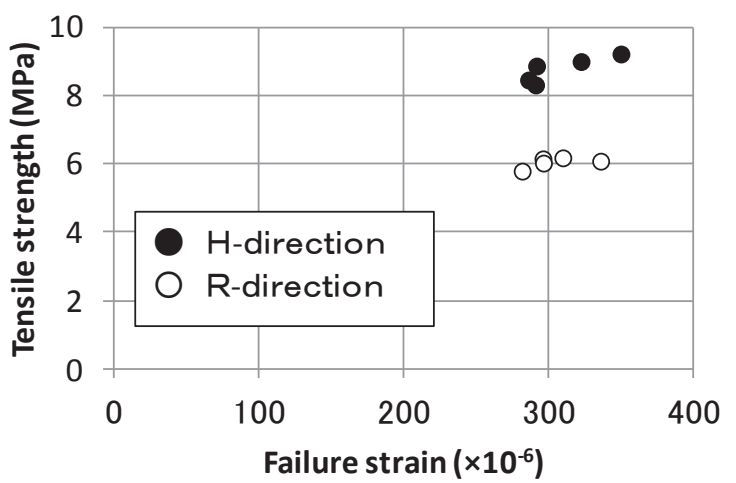

Fig.6 Relation between uniaxial tensile strength and strain.

小さい領域においてもクラックの進展が推察され, 非弾 性的な挙動を示す可能性があり，割線ヤング率を求める ことには問題がある可能性もあるが，ここでは応力ーひ ずみ曲線の傾きを評価する目的で割線ヤング率を求め たことを記しておく．引張破壊時におけるポアソン比を 求めた結果を Table3 に示す. ヤング率と同様にポアソン 比は弾性領域内で定義される值であり，引張破壊時のポ アソン比を求めることには問題がある可能性もあるこ とを断っておく、今回計測された周ひずみは最大で 24 $\times 10^{-6}$ 程度であり，ひずみの測定時の分解能が約 $3 \times 10^{-6}$ であることを考えると小さな值であった．ポアソン比の 值はばらつきが大きいものの, R方向とH方向とでは值 に差が見られ，R方向で值が小さいという結果となった. $\mathrm{H}$ 方向に比べて $\mathrm{R}$ 方向には載荷軸に垂直な方向のマイ クロクラックが多く含まれており，マイクロクラックの 
Table4 Result of micro crack observation.

\begin{tabular}{l|c|c}
\hline & Rift-direction $\pm 45^{\circ}$ & Hardway-direction $\pm 45^{\circ}$ \\
\hline Number of micro cracks & 62 & 20 \\
\hline Total microcrack length (mm) & 40.65 & 12.00 \\
\hline Mean micro crack length (mm) & 0.66 & 0.60 \\
\hline Maximum micro crack length (mm) & 2.25 & 1.88 \\
\hline Minimun micro crack length (mm) & 0.13 & 0.13 \\
\hline $\begin{array}{l}\text { Sstandard deviation of } \\
\text { micro crack length (mm) }\end{array}$ & 0.39 & 0.45 \\
\hline
\end{tabular}

\section{micro crack diameter $=0.63 \mathrm{~mm}$}

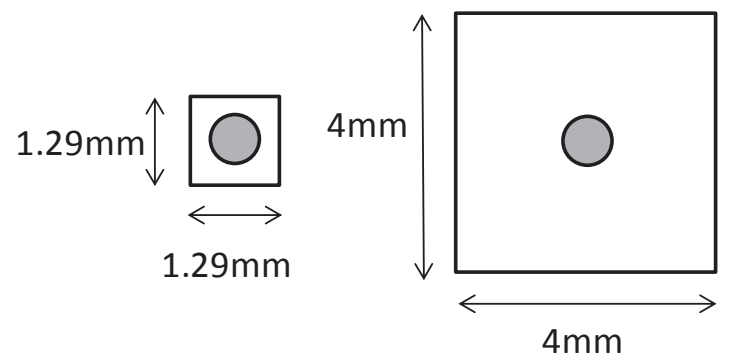

(a) R-direction

(b) H-direction

Fig.7 Schematic diagram of the crack.

進展が顕著であると考えられる。このため， R方向では $\mathrm{H}$ 方向に比べて弾性変形に比較して塑性変形の割合が 多く, 弾性変形によって収縮側に生じる周ひずみが小さ いことによるものと考えられる.

一軸引張強度と破壊時のひずみとの関係を Fig.6 に示 す。一軸引張強度はH方向と R方向で明らかな異方性が みられるのに対し, 破壊時のひずみには大きな差が見ら れない。

\section{4 考察}

\section{$4 \cdot 1$ ヤング率の異方性に関する考察}

ここではヤング率の異方性について，マイクロクラッ クを考慮した有効断面積に着目した考察を行う。一軸引 張試験は供試体に引張荷重を作用させるが，その際にマ イクロクラックの部分はクラックが開口する方向に変 形する．このため，マイクロクラックを除いた有効断面 積で荷重に抵抗するものと考える。第 2 章では Grain plane で作製した顕微鏡薄片を用いてマイクロクラック の観察を行った. Table2 に示したデータをマイクロクラ ックの方向別に整理した結果を Table4 に示す. 前述した とおり今回の計測では 2 枚の薄片で Rift 方向および Hardway 方向に一致する $40 \mathrm{~mm}$ の 2 本の直線の合計值で ある $80 \mathrm{~mm}$ の直線に交差するマイクロクラックを観察 した. その結果, Rift 方向 $\pm 45^{\circ}$ の方向には 62 個, Hardway 方向 $\pm 45^{\circ}$ の方向には 20 個のマイクロクラッ クが観察された．Rift 方向および Hardway 方向に一致す るように引いた直線には，それぞれ Rift plane および Hardway plane に平行なマイクロクラックが交差する確 率は低い.よって, Rift 方向 $\pm 45^{\circ}$ の方向には $40 \mathrm{~mm}$
たり $62 / 2=31$ 個, 寸なわち $40 / 31 \fallingdotseq 1.29 \mathrm{~mm}$ に 1 個のク ラックが存在すると考える. 一方, Hardway 方向土 $45^{\circ}$ の方向には $40 \mathrm{~mm}$ あたり 20/2=10 個，すなわち 40/10= $4 \mathrm{~mm}$ に 1 個のクラックが存在すると考える.

Table4 に示したようにマイクロクラックの数は Rift 方向 $\pm 45^{\circ}$ の方向と Hardway方向 $\pm 45^{\circ}$ の方向で約 3 倍 の差という明らかな差が見られたのに対し，マイクロク ラックの最大長さ，最小長さ，平均值および標準偏差に は大きな差は見られなかった。このため, マイクロクラ ックの長さの分布に関しては Rift 方向 $445^{\circ}$ の方向と Hardway 方向 $\pm 45^{\circ}$ の方向で大きな差が見られないもの と判断した。なお，計測したマイクロクラックの長さは 顕微鏡薄片上における観測長さであり，3 次元的に岩石 内に存在するマイクロクラックの長さとは異なる.今回 の計測は Rift方向および Hardway方向に一致するそれぞ れ $40 \mathrm{~mm}$ の直線の合計值である $80 \mathrm{~mm}$ の直線に交わる マイクロクラックの長さを計測しており, これは 2 次元 的な計測である. マイクロクラックの平均長さは, 本来 は 3 次元的にマイクロクラックを計測して評価すべき ものと考えられるが, 本研究では 2 次元的な計測にとじ まっている．ここではその結果から最も単純な仮定とし てマイクロクラックの平均長さは Table4 の $0.66 \mathrm{~mm}$ と $0.60 \mathrm{~mm}$ の平均の $0.63 \mathrm{~mm}$ と設定した。一軸引張試験時 の $\mathrm{R}$ 方向および $\mathrm{H}$ 方向の載荷軸に垂直な平面のマイク ロクラックの分布の模式図を Fig.7(a),(b)に示す。 マイク ロクラックは直径 $0.63 \mathrm{~mm}$ 虽でモデル化した.

顕微鏡薄片によるマイクロクラックの観察について は長田らの研究 ${ }^{2)}$ で詳しく報告されている. 長田らは総 観察面積が $16 \mathrm{~cm}^{2}$, クラックの総本数が数百のオーダー でマイクロクラックの観察を行っているが，これでも平 均的なクラック分布を計測するにはやや狭いと報告し ている．本研究では薄片に合計で $80 \mathrm{~mm}$ の直線を引き, これに交差する数十のオーダーのマイクロクラックを 観察しており, 平均的なマイクロクラックの長さを㛜密 に議論するには問題がある可能性がある。また，今回の 計測では 2 次元的な計測を行っているが，これを 3 次元 的なデータに補正するなど高度なデータ処理は施して いない. しかし， Table4 に示した各種の值から， Rift 方 向と Hardway 方向ではマイクロクラックの数には明ら かな差が認められるが，長さの分布は大きな差は見られ ないため，マイクロクラックを除いた有効断面を近似的 に求める目的で Fig.7 のような単純なモデル化を行うこ ととした。厳密なモデル化については今後の課題とした い.

Fig.7(b)から，まず，一軸引張試験時のH方向について, 断面積に対してマイクロクラックを除いた有効断面積 の比 $\mathrm{A}_{\mathrm{H}}$ を求めると（1）式のようになる.

$$
\mathrm{A}_{\mathrm{H}}=\left(4 \times 4-(0.63 / 2)^{2} \times \pi\right) /(4 \times 4) \fallingdotseq 0.98
$$

ここで、 $\mathrm{A}_{\mathrm{H}}$ はH方向の断面積に対する有効断面積の 比である. 次に, 一軸引張試験時の $\mathrm{R}$ 方向について求め ると（2）式のようになる. 


$$
\begin{array}{rlr}
\mathrm{A}_{\mathrm{R}} & =\left(1.29 \times 1.29-(0.63 / 2)^{2} \times \pi\right) /(1.29 \times 1.29) \\
& \fallingdotseq 0.81
\end{array}
$$

ここで $\mathrm{A}_{\mathrm{R}}$ はR方向の断面積に対する有効断面積の比 である.よって， R方向と H方向の有効断面積の比は, $\mathrm{A}_{\mathrm{R}}: \mathrm{A}_{\mathrm{H}}=0.81: 0.98 \fallingdotseq 0.83: 1$ となる。

一方， R方向およびH方向に荷重 P が作用した場合の みかけの応力 $\sigma_{\mathrm{R}}$ および $\sigma_{\mathrm{H}}$ とひずみ $\varepsilon$ の関係は, (3) 式および（4）式で表すことができると考える.

$$
\begin{aligned}
& \sigma_{\mathrm{R}}=\mathrm{P} /\left(\mathrm{A} / \mathrm{A}_{\mathrm{R}}\right)=\mathrm{E}_{\mathrm{R}} \varepsilon \\
& \sigma_{\mathrm{H}}=\mathrm{P} /\left(\mathrm{A} / \mathrm{A}_{\mathrm{H}}\right)=\mathrm{E}_{\mathrm{H}} \varepsilon
\end{aligned}
$$

ここで $\mathrm{A}$ は供試体の断面積, $\mathrm{A}_{\mathrm{R}}$ および $\mathrm{A}_{\mathrm{H}}$ は一軸引張 試験時の R 方向およびH方向の断面積 $\mathrm{A}$ に対する有効 断面積の比， $\mathrm{E}_{\mathrm{R}}$ および $\mathrm{E}_{\mathrm{H}}$ は見かけのヤング率である.

（3）式および（4）式から P，Aおよびをを消去し整 理すると（5）式が得られる.

$$
\mathrm{E}_{\mathrm{R}} / \mathrm{E}_{\mathrm{H}}=\mathrm{A}_{\mathrm{R}} / \mathrm{A}_{\mathrm{H}}
$$

よって，一軸引張試験時の R方向の見かけのヤング率 は、H方向に比べて $\left(\mathrm{A}_{\mathrm{R}} / \mathrm{A}_{\mathrm{H}}\right)$ 倍の值になる.

（1）式および（2）式で求めた $\left(\mathrm{A}_{\mathrm{R}} / \mathrm{A}_{\mathrm{H}}\right)$ は 0.83 であった。一方，Fig.4 に示したひずみレベルが小さい $50 \times 10^{-6}$ ひずみにおける割線ヤング率の比は, $26.8 \mathrm{GPa} / 34.3 \mathrm{GPa} \fallingdotseq 0.78$ であり, 0.83 とほぼ同じ值となる. よって, 引張応力下における R方向と $\mathrm{H}$ 方向のヤング率 の比は，マイクロクラックを除いた有効断面積を考慮す ることで説明できるものと考えられる.

\section{$4 \cdot 2$ 一軸引張強度の異方性に関する考察}

Fig.5 に示したように一軸引張試験時にはR方向およ びH方向ともにひずみレベルの増加に伴って割線ヤン グ率の值は低下していく。これは，マイクロクラックが 進展していき有効断面積が減少していくためと考えら れる. Fig.5に示したように，R方向およびH方向ともに 一軸引張破壊時のひず夕は $300 \times 10^{-6}$ 程度であった。こ の時の割線ヤング率の比を Fig.4 から求めると, $20.2 \mathrm{GPa} / 29.2 \mathrm{GPa} \fallingdotseq 0.69$ となる。よって，（3）式および (4) 式から求められる一軸引張破壊時の $\sigma_{\mathrm{R}} / \sigma_{\mathrm{H}}$ は $\mathrm{E}_{\mathrm{R}}$ $/ \mathrm{E}_{\mathrm{H}}=\mathrm{A}_{\mathrm{R}} / \mathrm{A}_{\mathrm{H}}=0.69$ となる. Fig.5 に示したR方向およ びH方向の一軸引張強度の平均值はそれぞれ $6.1 \mathrm{MPa}$ お よび $8.8 \mathrm{MPa}$ であり，その比は 0.69 となり（3）式およ び（4）式の值と一致する. すなわち, 一軸引張強度の 異方性は有効断面積を考慮すると説明可能であること， また，有効断面積を考慮すると R方向およびH方向は同 じ応力レベルで破壊していることが推察される.

\section{5 結言}

本研究では稲田花崗岩を用いて R方向およびH方向 に一軸引張試験を行い，異方性を確認した。また，有効 断面積に着目してヤング率および一軸引張強度の移行 性を考察した。本研究で得られた成果は以下のとおりで ある。

1 ）弾性波速度試験および顕微鏡薄片の観察によりマイ クロクラックの分布について検討した．その結果， Rift 方向 $\pm 45^{\circ}$ の方向に存在するマイクロクラックは
Hardway 方向 $445^{\circ}$ の方向に存在するマイクロクラック よりも数が多いことが確認できた。

2 ）一軸引張試験の結果，一軸引張強度，ヤング率およ びポアソン比は異方性を示すことがわかった。なお，一 軸引張破壊時のひずみには明確な異方性は見られない ことがわかった。

3 ）マイクロクラックを考慮した有効断面積に着目し, ヤング率および一軸引張強度の異方性を考察した。 その 結果, 有効断面積を考慮することでヤング率および一軸 引張強度の異方性を説明できることが分かった。

\section{参考文献}

1) Y. Kudo, K. Hashimoto, O. Sano and K. Nakagawa, "Anisotropy of granitic rock in the inland sea in western Japan", Journal of the Japan Society of Civil Engineering, No.382, III-7, pp.45-53(1987).

2) M. Osada, T. Yamabe and R. Yoshinaka, "Initial distribution of microcracks in Inada granite", Journal of the Japan Society of ENGINEERING GEOLOGY, Vol.39, No.6, pp.500-510(1999).

3) M. Kato, K. Koike, T. Yoneda and K. Kaneko, "A method for estimating three-dimensional distribution of microcrack orientations in rock", Shigen-to-Sozai, Vol.114, pp.909-917(1998).

4) W. Lin, T. Nakamura and M. Takahashi, "Anisotropy of thermal property, ultrasonic wave velocity, strength property and deformability in inada granite", J Journal of the Japan Society of ENGINEERING GEOLOGY, Vol.44, No.3, pp.175-187(2003).

5) K. Kasuya, "Experiment study on the mechanical characteristics of layered unisotropic rocks", Journal of the Japan Society of ENGINEERING GEOLOGY, Vol.20, No.3, pp.89-96( 1979).

6) O. Snano, Y. Kudo, S. Kawashima and Y. Mizuta, "Experimental determination of elastic constants of granite as an anisotropic body", Journal of the Society of Materials Science, Japan, Vol.37, No.418, pp.818-824(1988).

7) T. Yanagidani, S. Nishiyama and M. Terada, "Anisotropic development of dilatancy in uniaxially compressed granite", Journal of the Japan Society of Civil Engineering, No.382, III-7, pp.63-72(1987).

8) H. Kusumi, Y. Mine and K. Nishida, "Effect of stractual anisotropy on deformation properties of granite under cycric loading", Journal of the Society of Materials Science, Japan, Vol.46, No.9, pp.1029-1034(1997).

9) Y. Kohmura, "A fundamental study on stress-strain characterization of inada granit including post-failure region", Journal of the Society of Materials Science, Japan, Vol.61, No.3, pp.233-238(2012).

10) Y. Kudo, K. Hashimoto, O. Sano and K. Nakagawa, "Relation between physical anisotropy and microstructure 
og granite", Journal of the Japan Society of Civil Engineering, No.370, III-5, pp.189-198(1986).

11) Z. T. Bieniawski, "Mechanism of brittle fracture of rock part-III,-Fracture in tension and under long-term loading", International Journal of Rock Mechanics Mining Sciences, Vol.4, No.4, pp.425-430(1967).

12) S. S. Peng, "A note on the fracture propagation and time-dependent behavior of rocks in uniaxial tension", International Journal of Rock Mechanics Mining Sciences \& Geomechanics Abstract, Vol.12, No.4, pp.125-127( 1975).

13) W. Lin, M. Takahashi, Y. Fujii, S. Nishiyama and T. Takemura, "Deformability of several granitic rocks and gabbros in uniaxial tension", Journal of the Society of Materials Science, Japan, Vol.56, No.7, pp.654-659(2007).
14) Y. Fujii, T. Takemura, M. Takahashi, W. Lin and S. Akaiwa, "The feature of uniaxial tensile fractures in granite and their relation to rock Anisotropy", Journal of the Japan Society of ENGINEERING GEOLOGY, Vol.46, No.4, pp.227-231(2005).

15) S. Okubo and K. Fukui, "Complete stress-strain curves for various rock type in uniaxial tension", International Journal of Rock Mechanics Mining Sciences \& Geomechanics Abstract, Vol.33, No.6, pp.549-556(1996).

16) K. Fukui, F. Jin and S. Okubo, "Complete stress-strain curves of rock in uniaxial tension test", Shigen-to-Sozai, Vol.111, pp.25-29(1995).

17) K. Fukui, S. Okubo and T. Shimizu, "Failure process of rock in uniaxial tension", Shigen-to-Sozai, Vol.114, pp.925-930(1998). 